\title{
PENGELOLAAN OBJEK WISATA TIRTA EMPUL OLEH DESA ADAT MANUKAYA LET TAMPAKSIRING
}

\author{
Ni Putu Dewi Julianti, I Ketut Sukadana, I Putu Gede Seputra \\ Fakultas Hukum Universitas Warmadewa, Denpasar-Bali, Indonesia, Indonesia
}

\begin{abstract}
Abstrak
Indonesia merupakan negara yang sudah terkenal dengan keindahan objek wisatanya daerah di Indonesia yang objek wisatanya paling mencolok adalah Bali. Bali merupakan daerah yang terkenal dengan sebutan pulau seribu pura, kekentalan budaya adat yang diperpadukan dengan budaya modern yang masuk menjadi daya tarik tersendiri. Salah satu objek wisata di Bali yang menawarkan nilai estetika adalah objek wisata tirta empul dimana tempat yang dipercaya merupakan tempat pemandian (melukad) dengan beberapa mata air yang mampu membuat keadaan seorang menjadi lebih baik dari sebelum melakukan pemandian. Rumusan masalah: Bagaimana pengelolaan objek wisata Tirta Empul di Desa Adat Manukaya Let Tampaksiring dan apa hambatan yang dialami desa adat dalam memelihara dan mengelola objek wisata Tirta Empul di Desa Adat Manukaya? Beberapa masalah atau kekurangan dalam melancarkan tujuan kerjasama tersebut seperti niat dari masyarakat desa kurang dalam pengelolaan objek wisata tirta empul kemudian peralatan dan sarana yang menunjang pembersihan tempat wisata masing kurang dan banyaknya wisatawan yang tidak memperhatikan kebersihan dengan sembarangan membuang sampah yang membuat timbunan sampah padahal sudah banyak disediakan tempat sampah. Hasil dalam penelitian ini adalah pemerintah desa mengadakan Perjanjian antar dinas pariwisata yang bertujuan mengembangkan objek wisata Tirta Empul dan melestarikan budaya setempat, selanjutnya beberapa masalah atau kekurangan dalam melancarkan tujuan kerjasama tersebut seperti niat dari masyarakat desa kurang dalam pengelolaan objek wisata tirta empul kemudian peralatan dan sarana yang menunjang pembersihan tempat wisata masing kurang dan banyaknya wisatawan yang tidak memperhatikan kebersihan dengan sembarangan membuang sampah yang membuat timbunan sampah padahal sudah banyak disediakan tempat sampah.
\end{abstract}

Kata Kunci: Objek Wisata; Pengelolaan; Perjanjian dengan Desa Adat

\begin{abstract}
Indonesia is a country that is well known for the charm of its tourist attractions. The area in Indonesia having the most striking tourist objects is Bali. Bali has been an area known as the island of a thousand temples; the thickness of traditional culture combined with modern culture is its main attraction. One of the tourist objects offering aesthetic value in Bali is Tirta Empul, a place that is believed to be a place for bathing (melukad) with several springs that can make a person's condition better than earlier. The purpose of this research is two-fold: to examine the management of the Tirta Empul tourist attraction in the Manukaya Let Tampaksiring Customary Village and to reveal the obstacles experienced by the customary villages in maintaining and managing these tourist objects. This study uses a normative legal research design. The results show that the village government made an agreement with the Tourism Office with the aim of developing Tirta Empul tourism attraction and preserving local culture. Some problems or deficiencies in smoothing the goal of cooperation include the lack of intention of the village community in managing the Tirta Empul tourist attraction, equipment and facilities that support cleaning of their respective tourist attractions and the number of tourists who do not pay attention to cleanliness by littering carelessly despite the many trash cans provided, thus creating heas.
\end{abstract}

Keywords: Tourist Attraction; Management; Agreement; Traditional Village 


\section{PENDAHULUAN}

Setiap penyelenggaraan kenegaraan dan pemerintaha harus memiliki ligitimasi, yaitu "kewenangan yang diberikan oleh undang-undang. Dengan demikian substansi asas legalitas adalah wewenang. Menurut (Hernoko, 2010) Wewenang merupakan kekuasaan yang berasal dari hukum organisasi pemerintahan, yang dapat dijelaskan sebagai keseluruhan aturan yang berkenaan dengan perolehan dan penggunaan wewenang pemerintahan oleh subjek hukum publik. Kewenangan pemerintah dalam kaitan ini dianggap sebagai kemampuan untuk melaksanakan hukum postif dan dengan begitu dapat diciptakan hubungan hukum antara pemerintah dengan warga Negara (HR, 2003).

Untuk melaksanakan kewenangan tersebut pemerintah harus membuat peraturan perundangundangan sebagai dasar hukum pelaksanakan kewenangan salah satunya adalah perjanjian atau persetujuan. Persetujuan atau perjanjian adalah "Suatu peristiwa dimana seseorang berjanji untuk melaksanakan suatu hal. Dari peristiwa inilah timbul hubungan antara dua orang itu yang disebut dengan perikatan (Ketut, 2016).

Subjek hukum adalah pendukung hak dan kewajiban yang ditetapkan oleh hukum yang berlaku, dan semua manusia adalah subjek hukum. Dalam kenyataan hidup bermasyarakat dewasa ini, bukan hanya manusia yang oleh hukum diakui sebagai subjek hukum, melainkan entitas lain yang memenuhi syarat kesubjekkan yang ditentukan hukum. Untuk memenuhi kebutuhan manusia itu sendiri, ini dalam hukum juga diberikan pengakuan sebagai subjek hukum kepada yang bukan manusia. Subjek hukum yang bukan manusia itu disebut Badan Hukum (Ketut, 2016).

Dari batasan-batasan tentang badan hukum itu dapat diuraikan bahwa ciri-ciri badan hukum adalah:

1. Sekelompok orang yang memiliki tujuan.

2. Memiliki ruang masing-masing.

3. Punya dana yang dapat menunjang karirnya.

4. Sudah ada tanggung jawab sendiri dan resiko sendiri.

5. Bersifat terikat atau berkelanjutan.

6. Mempunyai hak menggugat dan digugat.

Perjanjian merupakan hubungan antara dua pihak atau lebih yang mana masing-masing pihak memiliki tujuan tertentu namun saling berkaitan satu dengan lainnya (Prasnowo \& Badriyah, 2019). berbagai barang dan benda bisa dijadikan objek dalam perjanjian demi terciptanya kesepakan antara para pihak yang melakukan perjanjian semisal pembagian harta gono gini, tanah, perkebunan dan masih banyak yang dapat dipergunakan. Setiap orang yang melakukan perjanjian pasti memikirkan matang- matang niat dan tujuannya namun bagi yang terikat dalam perjanjian dapat menimbulkan akibat hukum bagi mereka yang melakukan ingkar janji (Wahyuni, 2018).

Adapun unsur-unsur dari desa adat di Bali, sesuai dengan Perda Propinsi Bali Nomor 4 Tahun 2019 tentang Desa Adat Di Bali antara lain:

\section{Memiliki Pura Kahyangan Tiga yaitu: Pura Desa, Pura Puseh dan Pura}

Dalem, bisa juga Pura Puseh yang diempon oleh banyak desa adat.

2. Memiliki luas wilayah sesuai dengan keberadaan Pura Kahyangan Tiga

dengan persyaratan sebagai yaut (1) Tempat suci yaitu adanya Pura Kahyangan Desa dan memiliki harta benda seperti kekayaan Desa adat yang tidak kelihatan. (2) Masyarakat/krama, termasuk pengurus desa adat (3) Tanah wilayah Desa adat, seperti tanah ayahan desa, tanah laba pura dan kekayaan yang nyata (kas desa).

Tata cara pergaulan masyarakat adatnya yang dilandasi oleh jiwa paras- paros dan ngalap kasor yaitu gotong royong secara kekeluargaan berdasarkan atas kesadaran untuk mengabdikan diri kepada kepentingan bersama yang sudah berakar dalam budaya warga desa adat ternyata telah merupakan alat ampuh bagi usaha-usaha menyukseskan program-program pembangunan nasional, dan regional (Efendi, 2014). Suksesnya program pengadaan pangan, keluarga berencana, pelestarian lingkungan hidup, stabilitas keamanan desa dan mantapnya loyalitas warga desa kepada Pemerintah karena landasan ajaran Catur Guru Bhaktinya, serta terwujudnya suasana kehidupan di Bali yang rukun dan damai sebagai pancaran dari penghayatan dan pengamalan Pancasila, tidaklah terlepas dari peranan desa adat sebagai penuntut masyarakatnya. (Rahmiati, 2017).

Umumnya setiap manusia diberi hak untuk memilih dan menentukan jalan hidup mereka sendiri dimulai mencari pekerjaan sampai tempat tinggal dimana mereka inginkan serta memiliki kepercayaannya masing-masing selama tidak merugikan pihak lain atau lingkungan sekitar (Walian, 
2013). Pemerintah melalui peraturan yang di buat didasarkan pada pancasila sebagai dasar negara mendukung hak-hak setiap individu untuk berkembang dan meningkatkan kesejahteraan negara demi mencapai negara maju dengan mendukung melalui membuka lapangan pekerjaan seluasluasnya disetiap daerah di Indonesia. Berdasarkan paparan masalah di atas maka penelitian ini bertujuan untuk menjalin Perjanjian antar dinas pariwisata yang bertujuan mengembangkan objek wisata Tirta Empul dan melestarikan budaya setempat, selanjutnya untuk mengetahui beberapa masalah atau kekurangan dalam yang dialami untuk melestarikan objek wisata.

\section{METODE PENELITIAN}

Penelitian ini menggunakan hukum empiris berpatokan pada pencarian informasi langsung ke lapangan dan mengkaitkan dengan peraturan pemerintah yang berfokus pada tempat wisata tirta empul sebagai objeknya dan analisis dalam Informasi yang didapat dilakukan secara konseptual berkaitan dengan penelitian ini. Penelitian hukum empiris adalah pengkajian langsung kelapangan yang mengacu pada norma hukum yang terdapat dalam peraturan Perundang-undangan (Waluyo, 2002). Selama menyelesaikan penelitian peneliti tidak menyimpang dari hukum positif dan tetap melalui permasalahan yang dipaparkan di atas. Adapun jenis data yang digunakan adalah data primer dan data sekunder. Pendekatan masalah yang dipakai dalam penelitian ini adalah pendekatan sosiologi hukum. Pengumpulan dilakukan dengan cara Wawancara, Studi Dokumen dan Observasi/Pengamatan.

\section{HASIL DAN PEMBAHASAN}

Pemerintah dalam menjaga kelestarian daerah membuat suatu kelompok masyarakat di masingmasing desa guna menjaga terciptanya keharmonisan desa. Desa adat sendiri disetiap provinsi memiliki pengertian yang berbeda-beda di Bali khususnya Desa Adat menurut Perda Provinsi Bali Nomor 4 Tahun 2019 tentang Desa Adat di Bali adalah : Desa adat adalah kesatuan masyarakat hukum adat di Bali yang memiliki wilayah, kedudukan, susunan asli, hak-hak tradisional, harta kekayaan sendiri, tradisi, tata krama pergaulan hidup masyarakat secara turun temurun dalam ikatan tempat suci (Kahyangan Tiga atau Kahyangan Desa), tugas dan kewenangan serta hak mengatur dan mengurus rumah tangga sendiri.

Sebagai suatu ilustrasi dapat dikemukakan beberapa Ketetapan dan keputusan Parisada Hindu Dharma Pusat yang berkaitan dengan pengaturan desa adat, antara lain sebagai berikut:

1. Teruntuk masyarakat atau pendatang yang ingin tinggal di suatu desa diharapkan melaporkan karena jika dalam waktu 3 bulan tidak mendata baik sebagai pendatang atau bermaksud ingin menetap di desa tersebut akan mendapat sanksi mau tidak mau harus meninggalkan desa tersebut.

2. Peraturan setiap desa berbeda-beda sesuai dengan kesepakatan para anggota desa, awig - awig tersebut harus dipatuhi dan memiliki sanksi adat bagi yang melanggarnya.

3. Bertingkah laku dan memilah sikap serta kata-kata yang diucapkan dalam menjalani hidup bersama masyarakat guna menjaga keharmonisan suatu desa.

4. Melestarikan budaya disekitar tempat berada jangan sampai acuh tak acuh dalam menjalani hidup bermasyarakat demi meningkatkan kebersamaan krama desa adat.

5. Memiliki tempat persembahyangan yang wajib ada di sekitaran desa adat semisal Pura Dalem dan Pura Desa.

6. Melakukan persembahyangan secara rutin dan berkala antar krama desa adat memohon perlindungan dan keselamatan serta kemakmuran desa adat.

7. Mebraya merupakan kegiatan rutinitas yang mengikat para karma desa adat namun dalam keadaan tertentu krama desa adat dipermaklumkan jika tidak hadir dalam suatu kegiatan desa.

8. Segala tindakan dan prilaku krama desa adat harus sesuai dengan ketentuan awig - awig dan bila berkunjung ke desa lain agar mematuhi peraturan yang berlaku di desa tersebut karena peraturan setiap desa berbeda namun sifatnya mengikat.

9. Tanah ayahan desa merupakan tempat yang disediakan desa untuk karma desa adat agar memiliki tempat tinggal yang nyaman namun dengan pembagian yang sesuai. 
10. Sebagai pemimpin suatu desa diharapkan menjalin hubungan yang baik antara pimpinan desa lain guna menjalin tali silaturahmi dan saling menjaga antar desa. Membuat suatu organisasi para petinggi desa merupakan cara efektif membangun persaudaraan.

Perjanjian kerjama antara pihak Dinas Pariwisata dengan Desa Adat Manukaya bertujuan menciptakan kenyamanan, keamanan dan pelestarian objek wisata terjalin pada 06 April 2018 dengan pelaksanaan kerjasama sebagai berikut:

1. Perjanian kerjasama ini untuk Pihak Kesatu dilaksanakan oleh Dinas Pariwisata Kabupaten Gianyar selaku Organisasi Perangkat Daerah dan untuk Pihak Kedua Bendesa Desa Adat Manukaya Tampaksiring.

2. Segala risiko yang didapatkan dari penjualan tiket di luar tiket resmi dari Pemda tidak menjadi tanggung jawab Dinas Pariwisata Kabupaten Gianyar.

3. Untuk jam operasional Daya Tarik Wisata Tirta Empul buka dari jam 07.00 Wita Pagi sampai dengan jam 18.00 Wita dan apabila ada pungutan di luar jam operasional tidak menjadi tanggung jawab Dinas Pariwisata Kabupaten Gianyar.

Perjanjian kerja sama ini berlaku untuk jangka waktu 5 (lima) tahun terhitung sejak perjanjian ini ditanda tangani dan dapat diperpanjang kembali atas kesepakatan para pihak

Perjanjian kerjasama ini berakhir sesuai dengan jangka waktu yang disepakati, kerjasama ini dapat berakhir sebelum jangka waktu yang telah ditetapkan dengan ketentuan pihak yang mengakhiri memberitahukan maksudnya secara tertulis kepada pihak lainnya paling lambat 3 (tiga) bulan sebelumnya, selanjutnya perjanjian kerjasama iniberakhir atau batal demi hukum apabila ada ketentuan perundang-undangan dan atau kebijakan pemerintah yang tidak memungkinkan berlangsungnya perjanjian kerjasama ini tanpa terikat jangka waktu.

Hambatan yang ada dalam pengelolaan objek wisata di Kabupaten Gianyar ada beberapa tantangan/hambatan-hambatan antara lain hambatan internal dan eksternal hal tersebut sesuai dengan yang dikatakan oleh bapak A.A Ari Brahmanta antara lain:

1. Faktor eksternal yang sangat mempengaruhi pembangunan pariwisata Kabupaten Gianyar adalah: ancaman keamanan regional dan internasional seperti terorisme internasional. Kemudian faktor eksternal yang sekarang sedang maraknya yaitu mengani virus corona yang sangat mempengaruhi perkembangan pariwisata di kabupaten Gianyar, bahkan beberapa hotel di Bali dan Gianyar khususnya sudah memutuskan untuk merumahtanggakan sebagian tenaga hariannya maupun tenaga kontraknya, begitu besarnya dampak dari virus corona tersebut sehingga dapat menurunkan perkembangan pariwisata di kabupaten Gianyar.

2. Faktor internal seperti misalnya lemahnya dan rendahnya kesadaran pengelolaan sebagian besar daerah tujuan wisata dan aset-aset warisan, Belum efektifnya kelembagaan pengelolaan pemasaran dan promosi pariwisata terutama kinerja kelembagaan-kelembagaan pengelola pemasaran dan promosi pariwisata baik di pusat maupun di daerah, belum meratanya pembangunan pariwisata terutama di Gianyar bagian timur dan pengembangan masih terkonsentrasi di bagian barat (Ubud dan Payangan). (Wawancara dengan Bapak A.A Ari Brahmanta, Kepala Dinas Pariwisata Kabupaten Gianyar, pada tanggal 3 Maret 2020).

Dengan demikian dapat dikatakan bahwa Desa Adat sebagai definisi dalam mengelola Objek Wisata dan Daya Tarik Wisata di Tirta Empul Tampaksiring, sampai saat ini belum pernah ada hambatan yang berarti, jikapun ada itu telah dapat diambil solusi setelah diadakan musyawarah mufakat antara Pemerintah Daerah dengan Pengemong Pura dan Desa Adat.

\section{SIMPULAN DAN SARAN}

\section{Simpulan}

Berdasarkan hasil analisis data dapat disimpulkan bahwa Perjanjian antar dinas pariwisata dengan desa manukaya merupakan perjanjian yang bertujuan mengembangan objek wisata tirta empul dan melestarikan budaya setempat. Perjanjian yang dapat terbilang saling menguntungkan namun minim wanprestasi karena tujuan masing - masing pihak melestarikan objek wisata dengan menjaga keadaan dan keamanan di sekitar daerah objek wisata dengan pembagian $40 \%$ dana yang diperoleh dari penjualan tiket dipergunakan pemeliharaan objek wisata dan $60 \%$ dipergunakan dinas pariwisata meningkatkan keamanan daerah sekitar objek wisata. Yang kedua Kerjasama antara pihak dinas pariwisata dan desa adat dalam melestarikan objek wisata sudah baik namun menemui beberapa 
masalah atau kekurangan dalam melancarkan tujuan kerjasama tersebut seperti niat dari masyarakat desa kurang dalam pengelolaan objek wisata tirta empul kemudian peralatan dan sarana yang menunjang pembersihan tempat wisata masing kurang dan banyaknya wisatawan yang tidak memperhatikan kebersihan dengan sembarangan membuang sampah yang membuat timbunan sampah padahal sudah banyak disediakan tempat sampah. Virus merupakan masalah terbesar yang sering melanda tempat wisata karena tidak kasat mata, ada namun tidak terlihat semisal virus flu burung dan terorisme merupakan kejahatan luar biasa yang secara tidak langsung ada dilingkungan kita.

\section{Saran}

Adapun yang perlu disarankan oleh peneliti adalah Untuk dapat berjalannya perjanjian pengelolaan objek wisata Tirta Empul secara tertib, lancar dan aman, diharapkan kepada Pemerintah dan Desa Adat hendaknya transparans, baik dalam hal pendapatan dan pengeluaran dari hasil kerja sama tersebut, termasuk transparan dalam perekrutan tenaga di objek wisata Tirta Empul tersebut, sehingga tidak terjadi pelanggaran perjanjian pemungutan karcis di luar jam yang telah ditentukan dan pelangaran- pelanggaran yang lain, yang kedua Oleh karena seringnya terjadi isu-isu negative yaitu berita-berita yang tidak jelas dan tidak benar tersebut, dalam pengelolaan objek wisata, pemerintah daerah dan desa adat perlu mencari solusi dengan duduk bersama membahas permasalahan-permasalahan yang tengah terjadi sehingga isu-isu negatif tersebut tidak dapat berkembang lebih luas.

\section{DAFTAR PUSTAKA}

Efendi. (2014). Kewenangan Pengelolaan Sumber Daya Alam pada Era Otonomi Khusus di Aceh. Yustisia Jurnal Hukum, 3(2), 108-117.

Hernoko, A. Y. (2010). Hukum Perjanjian Asas Proporsionalitas dalam Kontrak Komersial. Kencana Prenada Media Group.

HR, R. (2003). Hukum Administrasi Negara (2nd ed.). UII Press.

Ketut, O. S. I. (2016). Hukum Perikatan. Sinar Grafika.

Prasnowo, A. D., \& Badriyah, S. M. (2019). Implementasi Asas Keseimbangan Bagi Para Pihak dalam Perjanjian Baku. Jurnal Magister Hukum Udayana, 8(1), 61-75.

Rahmiati, D. (2017). Demokrasi, Ham dan Militer. Penelitian Politik LIPI, 14(2), 109-288.

Wahyuni, A. (2018). Sistem Waris dalam Perspektif Islam dan Peraturan Perundang-undangan Di Indonesia. SALAM: Jurnal Sosial Dan Budaya Syar-I, 5(2), 147-160.

Walian, A. W. (2013). Konsepsi Islam Tentang Kerja Rekonstruksi terhadap Pemahaman Kerja Seorang Muslim. An Nisa'a, 8(1), 63-79.

Waluyo, B. (2002). Penelitian Hukum Praktek. Sinar Grafika. 